\title{
HARMONISING FAMILY LAW
}

\author{
Bill Atkin*
}

On 25 July 2006, Bill Atkin delivered his inaugural lecture after becoming a professor in the Law Faculty of Victoria University of Wellington. He took as his theme the state of disharmony in family law. While historically the focus of the law was narrow and consistent, a series of reforms has meant that family law's brief has widened and become something of a jumble. This is true of the law relating to adults as well as that relating to children. While there is plenty of scope to undertake a project to bring greater harmony to family law, the task may be forlorn. There are many forces militating against rationalisation of the law, ranging from diversity of family types and clashing ideologies to the realities of politics.

In preparing for this lecture, I went back to the inaugural lecture of one of the great family law scholars, Professor Michael Freeman. ${ }^{1}$ His opening line was "Inaugurals are strange occasions", and they are especially strange for someone like me who has been around these traps for quite some time. I also noticed that Professor Freeman's inaugural took place in the Chemistry Auditorium at University College London. What an odd place, I thought, to be delivering a lecture entitled "Towards a Critical Theory of Family Law" until I realised, of course, that we do talk about the chemistry in relationships. Much of family law is about this chemistry, or more often than not, the lack of it.

I am not talking to you in a chemistry lecture theatre like Easterfield 006 but here in the Hunter Council Chamber which is so apt. For this used to be the law library and is the place where many of us studied gainfully until the day when it was condemned as an earthquake risk.

\section{HARMONISING?}

I have called my lecture "Harmonising Family Law" because, perversely, family law is in a state of disharmony, the test used for granting, now very rarely, a separation order. ${ }^{2}$ When we unpack the law we discover something of a legal and policy jumble. Trying to tidy this up and bring uniformity

\footnotetext{
* Professor of Law, Victoria University of Wellington. A shortened version of this paper has been published in the New Zealand Law Journal.

1 M D A Freeman "Towards a Critical Theory of Family Law" [1985] Current Legal Problems 153.

2 Family Proceedings Act 1980, s 22.
} 
and clarity to the law sounds like a very good project. Even though we train our students to analyse, find holes, pull apart, argue both sides - a world view of opposites - most of us are more comfortable when the law is consistent, when it makes sense, when it is predictable. Hopefully lawyers have skills not only of analysis but also of synthesis, bringing order out of chaos.

I suspect that it is easier to achieve these goals in some areas of the law than others. I seriously wonder whether in $21^{\text {st }}$ century Aotearoa New Zealand it is really possible to produce a uniform code of family law that is acceptable to the wide cross-section of the public. The question is whether one size fits all. There was something like this 50 years ago, but social conditions were vastly different in those days and family law was a by-way on the legal map.

I propose to delve fleetingly into recent history, then illustrate ways in which family law is incongruent. I shall mention some of the important forces which militate against a harmonised family law and then conclude briefly by drawing some threads together.

\section{A BRIEF HISTORY}

Let me set out the historical context for this lecture: we shall return to many of the developments referred to. In the period immediately after the Second World War, family law as a discrete branch of the law barely existed. It was not really until the seminal work of Professor Don Inglis, later Judge Inglis QC, and Professor Dick Webb that family law was truly grounded as an area of practice and study. ${ }^{3}$ In those early days, family law, such as it was, was narrow in focus. It was relatively straightforward. The core concept was marriage and little else was contemplated. Even the law relating to children turned on the marital status of the parents. A child was legitimate if the parents were married, or could be legitimised if the parents married. Apart from the strong hold that religion and social mores had on people's relationships, the law of legitimacy was a very powerful incentive to marry. Your illegitimate child was severely disadvantaged unless adopted, and it was a married couple who usually adopted a child born out of wedlock who was offered for adoption. ${ }^{4}$

The abolition of illegitimacy occurred with the passage of the Status of Children Act 1969, less than 40 years ago. It was advanced by one of the country's most forward-looking Ministers of Justice, Ralph Hanan. The reasons for the abolition are not hard to find nor to agree with. A child was illegitimate through no fault of its own and, from the child's point of view, by accident. The child had no choice in the matter, even if the parents did. Why visit the actions of the parents on the child? No one presumably would argue against the Act today. Yet it may be seen as a turning point,

3 B D Inglis Family Law (Sweet and Maxwell, Wellington, 1960) (2 ed, vol 11968 and vol 2 1970) and P M Bromley and P R H Webb Family Law (Butterworths, Wellington, 1974).

4 See B J Cameron and P M Webb "Illegitimacy" in B D Inglis and A G Mercer (eds) Family Law Centenary Essays (Sweet \& Maxwell (NZ), Wellington, 1967). 
setting family law on a new path, or perhaps more accurately, a series of paths. ${ }^{5}$ For in one swoop, the need for marriage began to be eroded. I am far from suggesting that abolition of legitimacy was the sole cause of the more free-flowing lifestyle that we have today. Much was happening in the 1960s that was freeing people from prevailing moral frameworks. There is always the perennial question of whether society leads to law reform or the other way round. Nevertheless, the Status of Children Act 1969 did, I suggest, ultimately have the effect of unlocking much of the conceptual structure of the law hitherto. To put it another way, it would be impossible to conceive of today's laws on de facto relationships without illegitimacy first having been abolished.

In 1973, after the report of the McCarthy Royal Commission on social security, ${ }^{6}$ the domestic purposes benefit was formally incorporated into the Social Security Act $1964^{7}$ and in effect gave separated mothers an entitlement to State financial support. While the benefit was and still is available to single mothers and, on slightly different conditions, fathers the vast majority of recipients remain women whose marriage or de facto relationship has broken down and who are caring for children. As with the abolition of illegitimacy, few could seriously argue against State provision of this kind, not in a country where the underlying ethos has been that of the Welfare State, which survives despite the assaults it has faced. The alternative for mothers and children is destitution. The assurance of an income, even if little more than enough for the basics of life, makes the decision to leave a failed home that much easier.

Just two years later - the speed of law reform had become quick - the Labour Government introduced the Matrimonial Property Bill into Parliament. Unmarried cohabitation was now clearly on the agenda because the Bill contained provisions relating to de facto relationships. The new legislation, with its revolutionary equal sharing provisions, would have applied to such relationships that had lasted two years. ${ }^{8}$ Following a change of government, the legislation was passed but minus the reference to de facto relationships. It was obviously too much to stomach in the mid-1970s and it was not until the very early part of this century that de facto property claims were comprehensively legislated for. ${ }^{9}$ However, the underlying revolutionary nature of the legislation remained: marriage was seen as a partnership, not as before as two separate individuals, ${ }^{10}$ to be dealt with not according

5 It is true that in the preceding year, the grounds for divorce had been softened (Matrimonial Proceedings Amendment Act 1968) and the new Guardianship Act 1968 passed, but I suggest that these were evolutionary and in the end of less profound effect than the Status of Children Act 1969.

6 Report of the Royal Commission of Inquiry Social Security in New Zealand (Government Printer, Wellington, 1972).

7 See now Social Security Act 1964, ss 27A-27H.

$8 \quad$ Matrimonial Property Bill 1975, cl 49.

9 Property (Relationships) Amendment Act 2001, with accompanying measures dealing with maintenance and inheritance.

10 Married Women's Property Act 1884, but modified by the Matrimonial Property Act 1963. 
to the property law that applies to strangers but according to a specialised law that better reflects the overall realities of relationships.

The process by which family law ceased to be a by-way on the map and became a distinct branch led almost inexorably to the great package of reforms in 1980. The grounds for divorce were consolidated into one no-fault ground, irreconcilable breakdown proven by two years living apart. ${ }^{11}$ Although New Zealand had no-fault grounds from early in the $20^{\text {th }}$ century, ${ }^{12}$ it was not until the 1980 reforms came into force in 1981 that grounds such as adultery, cruelty and desertion were removed. Divorce, now called dissolution, became a very straightforward matter. Whereas under the old paradigm it exercised the minds of lawyers and judges greatly, today it barely rates a mention. The no-fault approach carries over into other issues. Fault is not totally irrelevant to child-care determinations, nor to property and maintenance, but usually it has to be clearly relevant to the matter in dispute to be taken into account. The classic matrimonial misdemeanours rarely fit the bill; instead, to take an example, burning down the family home may form part of an argument about the division of the parties' property.

The reform par excellence was the creation of the Family Court. If there was any doubt about the standing of family law, this step should have disabused the doubters. The no-fault move removed a major source of friction and dispute. So long as fault played a pre-eminent role in the outcome of cases, then an adversarial system, where the evidence of fault was properly tested, was necessary. Remove fault and it is less appropriate to see the parties as adversaries (even if they did so themselves). A special court system that preserved the conventional trial for the residual cases and that embraced mechanisms whereby the parties reached their own solutions became a much more sensible, if not inevitable, option.

Between 1980 and the 2001 package of reforms, two pieces of legislation are worth a mention: the Children, Young Persons, and Their Families Act 1989 and the Domestic Violence Act 1995. They deal with the question of violence in the home, whether directed at children or adults. In the supposedly no-fault era, the law and the agencies of the State coincidentally became more focussed on other kinds of blameworthy conduct.

The focus alters in another respect: it is less about the private legal relations of the parties and much more about the community's response to the phenomenon of violence. There is an underlying question here of a more general character: to what extent is family law part of private law as opposed to public law ${ }^{13}$ Perhaps this is a misleading question to ask, because we are unlikely to

11 Family Proceedings Act 1980, s 39.

12 Divorce and Matrimonial Causes Act 1920, s 4. For a discussion, see Hon Sir George McGregor "The Development of Divorce Law in New Zealand" in B D Inglis and A G Mercer (eds) Family Law Centenary Essays (Sweet \& Maxwell (NZ), Wellington, 1967). McGregor refers to an amendment in 1919 (at 23-24) but it appears to be the 1920 amendment that first introduced a pure non-fault ground.

13 Michael Freeman, among others, discusses this dichotomy: Freeman, above n 1, especially from 166. 
come up with a yes/no answer. However, it is important philosophically. If we see family law as essentially a branch of private law, we are more likely to take a laissez faire attitude and provide a framework within which people can operate for themselves. If we emphasise the public law aspects of family law, then we are much more likely to countenance the State or the community having a crucial role to play in the outcome of cases. Where there has been violence, we are likely to accept that the matter should not simply be left to the parties, especially where the victims are children or vulnerable adults such as elder citizens.

The $21^{\text {st }}$ century has seen a package of legislation that is on a par in importance with that of 1980. The reforms in 2001 tackled de facto relationships and widowed parties, although full inheritance reform is still warranted. ${ }^{14}$ Same-sex couples were part of this process, culminating in the Civil Union Act 2004. Finally, there is the Care of Children Act 2004. Most of the developments this century have been controversial.

In summary, over the course of a half-century family law has found its feet. It has moved through a series of reforms as attitudes and social conditions have changed. It is now far less concerned with the formal concept of marriage and more with the actual reality of people's relationships. It is no longer interested in adulterous affairs but is very concerned with violent conduct. Many points in the law have been stood on their heads. It is hardly surprising that the law has developed a bit like topsy and is something of a jumble. To this we now turn.

\section{THE STATE OF DISHARMONY}

\section{A Adult Relationships}

The starting point when looking at the law relating to adults is the recognition of different relationships. Whereas historically there was only one concept to think about, namely marriage, now there are three and possibly four. These are marriage, civil unions, de facto relationships and other relationships falling outside these categories. Examples of the latter include "close personal relationships", a phrase taken from the Domestic Violence Act 1995 and covering a variety of associations, including boyfriend/girlfriend relationships as well as platonic friendships. ${ }^{15}$ The 1995 Act also covers family relations. While there is no institutionalisation of these associations, they are nevertheless legally recognised for certain limited purposes.

In New Zealand, the de facto relationship can now hardly be classified as a purely private arrangement. If you have entered such an arrangement, and in general if it has lasted for three years, then the same law on property division, maintenance, intestacy and family protection as marriage will by and large apply. In many other areas of the law, including taxation and welfare, de facto relationships, civil unions and marriages are treated similarly.

14 For example, the Wills Act 1837 (Imp) still governs aspects of New Zealand's inheritance law.

15 Domestic Violence Act 1995, s 4(1)(d). 
It looks as though we have harmony!

However, this belies a great deal of underlying misgivings. On one side of the ledger, there are those who greet this unifying of the law with some alarm. They might argue that "marriage has stood the test of time and it is inappropriate to elevate other relationships to the same level. Marriage should be preserved as the privileged institution." Any suggestion that this is legally impermissible on discrimination grounds is swept away, at least for the time being, by the majority decision in Quilter $v$ Attorney-General. ${ }^{16}$ The same conclusion is reached by others but for very different reasons. The libertarian perspective emphasises freedom of individual choice and thus objects to legislation that imposes a statutory regime on people who have not opted for it. At the time of the passage of the 2001 reforms, there were attempts to apply the law only to those who opted into it, instead of the other way round. ${ }^{17}$ While the logic of opt-in has some appeal, it nevertheless leaves out of the loop a raft of relationships, which have to be dealt with some other way.

The other side of the ledger asks, pace Quilter, why Parliament has created a new institution, namely the civil union, ${ }^{18}$ which appears to serve much the same legal and social purpose as modern marriage. While the civil union and marriage are very similar in their legal consequences, there are some subtle differences. Take two examples. First, a civil union couple cannot adopt, although a little oddly one partner can do so as an individual. ${ }^{19}$ Secondly, a civil union does not automatically revoke a pre-existing will (not made in contemplation of the union), as happens with marriage. ${ }^{20}$ The first of these examples is controversial, but interestingly England and Wales, which usually lags behind New Zealand in law reform, allows same-sex couples to adopt. ${ }^{21}$ The second example makes some sense because most civil union couples are likely to have lived together for some time and their wills will have been made on the basis of the continuation of the relationship. It would be unfortunate if the civil union unnecessarily undid what was entirely appropriate. In passing, we may note that the revocation rule may also no longer be appropriate for most couples getting married as they are also likely to have cohabited prior to marriage.

The more fundamental difference between civil union and marriage is that same-sex couples can become civil union partners but not marriage partners. Whatever one's view of this, Parliament has made a policy decision to give official recognition to same-sex couples by way of a registration of the relationship. Once this choice has been made, why complicate the law and not harmonise it as

16 Quilter v Attorney-General [1998] 1 NZLR 523 (CA).

17 Spouses and partners can contract out of the Property (Relationships) Act 1976 under Part 6.

18 Civil Union Act 2004.

19 Adoption Act 1955, s 3 .

20 Wills Act 1837 (Imp), s 18 and Wills Amendment Act 1955, s 13.

21 Adoption and Children Act 2002, ss 49, 50 and 68(3). 
has happened in other jurisdictions such as Canada by extending the privileges of marriage to samesex couples? Perhaps it does not matter because civil union partners have all that they need in terms of official sanction and have recourse to various sets of laws such as those dealing with property and inheritance. Professor Austin powerfully answers this when he describes the important symbolism that society can lend to (or withhold from) loving relationships and says: "At the very least, the law should ensure that arbitrary distinctions do not exist between the symbolic resources available to different sectors of society". ${ }^{22}$

To sum up at this point, the official legal organs of New Zealand society have been engaged in a process of harmonisation and dissonance at much the same time. At the formal level we now have two institutions instead of one. At the practical level of resolving particular problems like property division, we add a third, the de facto relationship, with the result that the three categories of cohabitation are treated in much the same way. How rational are these laws which now apply in common? If we explore them a little we find that discordance of a different kind emerges.

\section{B Relationship Property and Maintenance}

At first sight, the Property (Relationships) Act 1976 appears to be reasonably harmonious, with a clear message that core assets and the product of the partnership are ordinarily to be divided equally. Indeed, when the 2001 reforms were enacted, the underlying philosophy was reinforced by narrowing the exceptions to equal division, and extending it to de facto relationships and widowed parties. $^{23}$

From a strictly legal point of view, the inclusion of de facto relationships has not been hugely problematic. After an initial hiatus of a couple of years, more de facto relationships cases are going through the courts under the new rubrics. In most instances, the problems that surface are much the same as those that could arise for married couples. In addition, however, judges may have to decide whether marginal situations amount to a de facto relationship and, because of the rule that, subject to exceptions, they have to last for three years to qualify, ${ }^{24}$ judges may have to determine when a relationship began and when it ended.

These cases largely turn on their facts. No black and white definition of a de facto relationship can really be devised, but judges are able to come up with sensible conclusions. As Gendall and Ellen France JJ have put it: ${ }^{25}$

22 Graeme W Austin "Essay: Family Law and Civil Union Partnerships - Status, Contract and Access to Symbols" (2006) 37 VUWLR 183, 197.

23 Rather confusingly, Parliament altered the name of the Act but the year 1976 was retained.

24 Property (Relationships) Act 1976, ss 2E and 14A.

25 Scragg $v$ Scott [2006] NZFLR 1076, para 37 (HC) Gendall and Ellen France J. For another High Court judgment on the subject, see $G v B$ [2006] NZFLR 1047 (HC). 
The test must inevitably be evaluative, with the Judge having to weigh up as best he or she can all of the factors ... and applying a common sense objective judgment to the particular case ... Generalisations are to be avoided because every case is fact specific.

So far so good. We appear to have a relatively coherent looking scheme that works moderately well. However, such an assessment belies the reality. The 2001 reforms made other changes that muddy the waters enormously. In essence, the law, out of genuine concern for a party who has been locked into a relationship to their financial disadvantage, now confuses the division of property with ongoing income maintenance, in other words the distinction between capital and income.

The 2001 amendments to the property division rules introduced new powers under which the Court can award compensation for economic disparity. ${ }^{26}$ The claimant must show that there is a significant difference in the parties' respective future income and living standards and that this difference is the result of the division of functions while they lived together. Compensation is not automatic. The Court has a discretion whether or not to make any award and may take into account likely earning capacity, child care and "any other relevant circumstances". Parliament has given no guidance on how the amount of an award is to be calculated beyond the phrase "for the purpose of compensating".

These powers look both backwards to the past division of functions and forwards to future income, living standards and earning capacity. These so-called "ED" claims have become big business. They have created extra work for lawyers and actuarial experts. Each side can wheel in an expert to further their side of the argument and the chances of agreement are slight. In the same case, an expert may recommend either no award or something very small while the other expert suggests a figure of over $\$ 1$ million. Many cases have gone to the courts and you can reckon on a $50 / 50$ chance of success.

The Court of Appeal in its recent decision in $M v B$ [Economic disparity] has hardly assisted in clarifying the matter. ${ }^{27}$ Robertson $\mathrm{J}$ considered that the setting of the amount was a matter of impression and should not be undertaken by following a rote formula. ${ }^{28}$ Hammond $\mathrm{J}$ thought that the law does not require an outcome of arithmetical equality, but in determining the level of compensation the Court should spell out how the figure was reached. ${ }^{29}$ An impression test is largely guesswork, but, if we rely on a formula, that proves to be largely guesswork as well because of so many future uncertainties.

26 Property (Relationships) Act 1976, ss 15 and 15A.

$27 M v B$ [Economic disparity] [2006] NZFLR $641[M v B]$. The High Court judgment is found at $B v M$ [2005] NZFLR 730 (HC).

$28 M v B$, above $\mathrm{n} 27$, paras 146-147 Robertson J.

$29 M v B$, above $\mathrm{n} 27$, paras 266 and 271 Hammond J. 
Much more could be written solely about ED claims. Enough has been said to indicate that they have brought a note of disharmony into an otherwise coherent scheme. They are speculative, adversarial and costly, all things that family law tries to avoid.

There is, however, a deeper problem with ED claims and this is the confusion with the law of maintenance. Former spouses and de facto and civil union partners can seek maintenance quite independently from child support. ${ }^{30}$ Maintenance is usually paid on a periodic basis but can also be awarded in a lump sum form. The party who can afford to do so pays an amount to the person who needs it. Following changes made in 2001, the assessment of a person's reasonable needs can be linked to the family's prior standard of living and so is not capped at the breadline.

An ED claim that is concerned with future earning capacity and a maintenance claim that is concerned with future needs deal broadly with the same question. It is not surprising that Hammond $\mathrm{J}$ in $M v B$ thought that economic disparity compensation is "the functional equivalent of a lump sum for future maintenance". ${ }^{31}$ On the other hand, William Young $\mathrm{P}$ denied that it was capitalised maintenance, even though he thought that compensation may obviate the need for maintenance in some cases. ${ }^{32}$ Whichever approach is nearer the truth, it is not too difficult to conclude that we now have two major strategies with different ground rules for tackling roughly the same problem namely, the income differential between parties on the breakdown of a relationship.

$M v B$ is worthy of a lot more time than is available here. It was also about the value of a law partner's so-called "super-profits" (the extra value that a person may tap into by, for example, belonging to a large firm). The appellate judges, while agreeing in the end on a value, adopted different approaches in reaching their conclusions. A downstream consequence was that the wife gained a lot more by way of relationship property, ${ }^{33}$ which on the face of it should have affected both the ED claim and the maintenance one. However, the Court declined to accept the logic of this.

In addition, the Court of Appeal made a separate determination about the income that the husband earned between the date of separation and the date of hearing. Typically under section 9(4) of the Act, property, including income, acquired after the date of separation is the person's own separate property, thus falling outside the usual division rules (although there is power to treat it as relationship property if it is just to do so in the circumstances). The Court of Appeal, however, held that the husband's income which could notionally be connected to the super-profits was relationship property under section $8(1)(1)$, that is as income or gains derived from other relationship property.

30 Family Proceedings Act 1980, ss 60-70B.

$31 M v B$, above $\mathrm{n} 27$, para 272 Hammond $\mathrm{J}$.

$32 M v B$, above $\mathrm{n} 27$, para 191 William Young $\mathrm{P}$.

33 Precisely how much is unclear because the Supreme Court ordered that the Court of Appeal judgment be redacted so that financial details be disguised. Subsequently the case was settled and so the Supreme Court did not hold a substantive hearing. 
William Young P stated that this aspect of the case certainly troubled him and he accepted that from the husband's point of view, the wife was "having her cake and eating it too." ${ }^{34}$ He nevertheless went along with the majority. With respect, it is suggested that the ruling represents a triple payment for the wife: she has a share in the past earnings, a share in the future earnings via the economic disparity award and a share of the income through maintenance. Can this possibly be right?

One final point I want to mention is that the Court in $M v B$ also considered whether maintenance or economic disparity should be determined first. As we have seen, they deal with similar points and can have an impact one on the other. Robertson J took the view that maintenance had to be determined only after property issues had been resolved, William Young P thought the order of resolving the different questions not particularly important, and Hammond $\mathrm{J}$ thought that in a large number of cases property will be decided first as in the past. ${ }^{35}$ In my view, it should not matter in which order the questions are dealt with, so long as the effect of one is fully taken into account when assessing the other. ${ }^{36}$

The lesson from all this is that law reform should be done properly. There is now an urgent need for the law on the inter-relationship of capital and income to be overhauled, and much clearer parameters established. Arguably, economic disparity claims should be replaced by an enhanced maintenance regime that takes more fully into account the effects of intimate relationships.

\section{Children}

The law relating to children is distinctly fraught. It is also the area where the voices of lobby groups are heard the loudest and where different ideological positions are hardest to resolve.

Let us go straight to the most obviously identifiable problems:

- What are the appropriate roles for parents and the family?

- Where do children's rights fit in?

- What is the appropriate role for the State?

1 Do parents have rights? What about the family?

Every so often we hear the rhetoric of parents' rights. It tends to be assumed that parents have superior rights with respect to their children over strangers, other family members and the State. In many instances this is true, but not because they are parents but because they are the child's

$34 M v B$, above n 27, para 176 William Young P.

$35 M v B$, above n 27, para 125 Robertson J, para 207 William Young P and paras 247 and 250 Hammond J.

36 For a fuller discussion of this, see B Atkin "The Disparity in Economic Disparity - The Need for a Fullscale Overhaul of Sections 15 and 15A and Maintenance" in New Zealand Law Society Family Law: The New Era - Professionalism in the Family Court (Conference paper, Wellington, October 2005). 
guardians. Under the Care of Children Act 2004, guardians have significant tasks (including duties, powers, rights and responsibilities) in relation to the child - daily care, naming, education, religion residence, language, culture and so on. ${ }^{37}$ The concept of guardianship is the cornerstone of the Act. Yet at the same time, the Act speaks with a forked tongue, for section 5 states that "the child's parents and guardians should have the primary responsibility, and should be encouraged to agree to their own arrangements, for the child's care, development, and upbringing" (emphasis added). What are we supposed to make of this?

The importance of the question is because on the one hand not all parents are guardians and on the other non-parents can be guardians. For example, the father of the one-night stand child is a parent, but not a guardian per se (he may be if on the birth certificate or if he has got a court order appointing him a guardian). ${ }^{38}$ A step-parent may be a guardian (and the Act now contains a new doit-yourself procedure for appointment of step-parents as guardians), ${ }^{39}$ or a family member such as a grand-parent, or a foster-parent - indeed potentially anyone - may be appointed a guardian by the court. So, talk of parents' rights needs to be framed very cautiously.

This is reinforced by a novel but confusing provision contained in the Act. Under section 16(5), guardians must act jointly. The real impact of this provision is hard to ascertain, especially as there is a curious bit in parentheses that almost countermands the main rule - "in particular by consulting wherever practicable with the aim of securing agreement". Does this mean that acting jointly has no more substance than a bit of sly consultation? Or does it mean what it says: "must act jointly"?

The courts have also considered the role of parents. Gendall and Ellen France JJ had to deal with a difficult situation where parents sought custody of a boy who had lived with the mother's cousin for 6 years from the age of 14 months - in other words most of his life. ${ }^{40} \mathrm{He}$ had been moved to the cousin because of his parents' violent home. The parents now claimed that they had sorted out their differences and could look after the boy satisfactorily. This was a politically charged case. The Member of Parliament for Nelson had waded in on the parents' side and was subsequently found guilty of contempt. ${ }^{41}$ This was not a case to be tried in the media and in some ways signals a cautionary note in the debate over how open the Family Court should be. What Gendall and Ellen France JJ had to focus on was not the political intrigue but the future of a young boy.

37 Care of Children Act 2004, ss 15 and 16.

38 Care of Children Act 2004, ss 17-20.

39 Care of Children Act 2004, ss 21-25. See E Watt "The DIY Procedure for Appointing Step-parents as Additional Guardians" (2006) 5 NZFLJ 118.

$40 K v G[2004]$ NZFLR 1105 (HC).

41 Solicitor-General v Smith [2004] 2 NZLR 540 (HC) (conviction) and [2004] 2 NZLR 570 (HC) (sentence). 
The judges cited a landmark House of Lords' judgment of nearly 40 years ago, where it was held that there is no presumption in favour of unimpeachable parents over long-term foster parents. ${ }^{42}$ So, parents do not have "a pre-eminent position":43

The words "rights of parents" appear to have assumed some prominence from the correspondence of the parents, or their supporters, in this case. That may be understandable from their point of view, but it misses the true focus .... There can be only one first consideration, and it is the paramount consideration of the welfare of the child.

The welfare of the child, now under the Care of Children Act 2004 the "welfare and best interests of the child", is an individualised assessment. In the instant case, the High Court agreed with the Family Court that the boy should stay where he was.

The model advanced in the Care of Children Act 2004 is largely, though not wholly, that of the proverbial nuclear family, where guardians who will often equate to the parents are the key players. Two other pieces of legislation however point in different directions and reinforce the view that there is little harmony in the law relating to children.

First, the Child Support Act 1991 deals with the important question of financial support for children. Apart from the very rare exception of someone declared to be a step-parent, ${ }^{44}$ the Act sets its sights firmly on parents and effectively no one else. Most of these parents will have been part of a nuclear family that has split. A few will be fathers who had only a fleeting association with the mother. The policy that parents, and this commonly means fathers, should pay for their children is not usually questioned. ${ }^{45}$ Yet, nowhere in the Act are the welfare and best interests of the child mentioned. The scheme is run by the Inland Revenue Department, using a set formula, and is carved off from the rest of family law. It does not need to be in tune with the rest of the law. Baroness Hale, now the first woman in the judicial branch of the House of Lords and a distinguished family law and mental health scholar, has criticised the British equivalent for this very reason. She said, speaking extra-judicially, that "we have now separated the financial and caring responsibilities of parenthood, and I wonder how far this really serves the child's interests". ${ }^{46}$

$42 J v C$ [1970] AC 668 (HC). This has been reaffirmed by the House of Lords in In re G (children) [2006] UKHL 43.

$43 K v G$, above n 40, para 23 Judgment of the Court.

44 Child Support Act 1991, s 99.

45 For a possible contrary argument, see B Atkin "Financial Support - Who Supports Whom?" in M Henaghan and B Atkin (eds) Family Law Policy in New Zealand (2 ed, Butterworths, Wellington, 2002) especially 155 and following.

46 The Rt Hon Mrs Justice Hale (as she then was) "The Eight ASARCO Annual Lecture 1997: Private Lives and Public Duties: What is Family Law For?" (1998) 20 JSWFL 125, 132. 
If we ever try to harmonise family law, the Child Support Act 1991 must not be allowed to escape attention. Among other things, the welfare of the child demands that the relationship between financial payments and involvement in the child's life be grappled with. Current disincentives to providing a child with extra help should be removed. Allowing a proportion of payments that would otherwise be retained by the State to be passed on for child care should be re-considered.

Secondly, the Children, Young Persons, and Their Families Act 1989 deals with child protection and youth justice. My focus is on the former: children in need of care and protection. We immediately notice an oddity, for the Care of Children Act 2004 misses out a whole lot of the law relating to the care of children. It is misnamed but the more important point is that the 1989 Act embraces a philosophy radically different from that in the 2004 Act. They are so far apart that it is hard to see how they can be reconciled.

The central focus of the 1989 Act is the family, not parents or guardians. Under section 13(b), the Act refers to the principle "that the primary role in caring for and protecting a child or young person lies with the child's family, whānau, hapū, iwi and family group". This is a clear statement but it is utterly inconsistent with the Care of Children Act 2004's emphasis on parents and guardians.

A major critique of the 2004 Act is that it is monocultural and Euro-centric in focus and in particular fails to take account of the Māori perspective, where the whānau is central. The point is made in a compelling way by Hall and Metge in the context of the Guardianship Act 1968 (the precursor to the Care of Children Act 2004). ${ }^{47}$ The Care of Children Act 2004 makes passing reference to Māori values but not in any meaningful way - indeed in a totally confusing way. For example, section 5(b) says that "the child's relationships with his or her family, family group, whānau, hapū, or iwi, should be stable and ongoing" which is fine, but then is confounded by a bewildering phrase in brackets which reads: "in particular the child should have continuing relationships with both of his or her parents". The Care of Children Act 2004 is a muddle as it is, but to have the muddle so manifest by the juxtaposition of these concepts is bizarre.

Hall and Metge see the 1989 Act, in contrast, as reflecting Māori aspirations because of its focus on the family rather than parents. It is also much more in line with Pacific ideals and probably those of many other sections of New Zealand society. The central decision-making body is the family group conference. This brings together a range of people with blood ties to the child but also those to whom the child has psychological bonds. It is a process that does not surface at all in the Care of Children Act 2004. No provision, even on a voluntary basis, is made for family group conferences as the family is largely unimportant. This might be explained on the basis that the Care of Children Act 2004 deals in particular with the position of children on their caregivers' break-up, whereas the

47 D Hall and J Metge "Kua Tutū Te Puehu, Kia Mau Māori Aspirations and Family Law" in M Henaghan and B Atkin (eds) Family Law Policy in New Zealand (2 ed, Butterworths, Wellington, 2002). See also the discussion of Judge Annis Somerville "Whanaungatanga in the Family Court" (2006) 5 NZFLJ 140. 
Children, Young Persons, and Their Families Act 1989 deals with children whom caregivers may quite possibly have abused. Arguably the former is a private situation whereas the latter involves the wider community. We may even question how well different cultural approaches actually work. Nevertheless, the premises of our statutes on children are fundamentally opposite.

The picture with regard to the abuse of children is not complete without mention of the Domestic Violence Act 1995. While the principal legal mechanism for dealing with the problem is the Children, Young Persons, and Their Families Act 1989, the 1995 Act can also be invoked with a totally different set of jurisdictional rules and outcomes. This is more evidence of the disharmony of the law.

\section{Do children have rights?}

Up to this point, I have been talking about the tension between parents and families, and sometimes outsiders. What about the children? One of the most impressive signs of international unity in family law is the United Nations Convention on the Rights of the Child, ratified by every nation except Somalia and the United States. ${ }^{48}$

Michael Freeman has recently written a staunch defence of children's rights in a review essay called "What's Right with Rights for Children", ${ }^{49}$ reviewing a book called What's Wrong with Children's Rights. ${ }^{50}$ He says: ${ }^{51}$

Rights are important because they are inclusive. They are universal, available to all members of the human family ... . It has always been to the advantage of the powerful to keep others out. It is not, therefore, surprising that adults should want to do this to children, that they should wish to keep them in an often imposed and prolonged dependence which history and culture show to be neither inevitable nor essential.

The emblematic case on children's rights is Gillick $v$ West Norfolk and Wisbech AHA, ${ }^{52}$ where the House of Lords by the narrowest of margins held that contraceptive advice could be given to a minor without the parents' knowledge, so long as certain conditions were fulfilled. One of the main ones is that the minor has the necessary level of maturity, or what has come to be known as Gillick competence. However, the case stands for a much wider proposition: it is about children's growing autonomy in general. It is controversial: it challenges "parents' rights" and it does not rest on arbitrary age limits when suddenly a younger person can act like an adult.

48 The Convention is found in the Children's Commissioner Act 2003, sch 2.

49 Michael Freeman "What's Right with Rights for Children" (2006) 2 Int'l J L in Context 89.

50 M Guggenheim What's Wrong with Children's Rights (Harvard University Press, Cambridge (Mass), 2005).

51 Freeman, above n 49, 89.

52 Gillick $v$ West Norfolk and Wisbech AHA [1986] AC 112 (HL). 
How does New Zealand law stack up against the Gillick test? The application of the decision has never been tested in New Zealand. The Care of Children Act 2004 was the great opportunity to determine the place of Gillick in the law and indeed one of the stated purposes of the Act is to "recognise certain rights of children". ${ }^{53}$ But there are in fact very few signs of rights recognition. The Act, like much of the law, is still very adult-focussed. Where minors are given autonomy it still turns on an arbitrary age, not on their level of maturity. ${ }^{54}$ Generally speaking the child does not have any right to initiate proceedings under the Act, although there is an exception in section 31(2) which enables the child to ask to be placed under the guardianship of the court (and does not even need to apply through a litigation guardian, the old guardian ad litem). This can be compared with the more extreme example of the Child Support Act 1991, where, counter-intuitively, a child has no right at all to claim its own child support. ${ }^{55}$ A child can challenge a guardianship decision under section 46 but only on reaching the age of 16 .

There are a couple of modest signals in the description of the role of guardians that something of the Gillick philosophy has crept through. Guardians are to contribute to the child's development, and are also to determine "with the child" or help "the child to determine" important questions, ${ }^{56}$ the choice of secondary school perhaps being a good example. Under section 6 the child must be given reasonable opportunities to express views, irrespective of age and maturity, but while the views must be taken into account, they can also be completely ignored..$^{57}$

I am not suggesting that the tensions created by the children's rights philosophy are simple to resolve. How, for instance, should a court deal with a girl's request, as happened recently, that her parents be forced to stop a campaign against what they saw as her philandering and the inadequate response of the authorities? ${ }^{58}$ The Judge favoured the girl. What I am suggesting is that, though a complication, children's rights must be given a central place in any attempt at harmonising the law.

3 Where does the State fit in?

Advocates of parental rights often pitch their case as one against the intrusive powers of the State. ${ }^{59}$ There is no doubt a tension here and a source of great dispute. However, the State has long had an umbrella oversight of vulnerable sections of the community. At common law the superior

53 Care of Children Act 2004, s 3(1)(b).

54 For example, the age of 16 for medical decisions: Care of Children Act 2004, s 36.

55 Hyde v CIR [2000] NZFLR 385 (FC).

56 Care of Children Act 2004, s 16(1)(b)-(c).

57 See M Henaghan "Case Note: Children's Views - Two Steps Forwards, One Step Backwards" (2006) 5 NZFLJ 154

$58 E J W v D W[2006]$ NZFLR 393 (FC).

59 See for instance the book reviewed by Michael Freeman: Guggenheim, above n 50. 
courts have jurisdiction over children and those with mental and intellectual disabilities based on the notion of parens patriae. The statutory form of this as far as children is concerned is found in sections 30-35 of the Care of Children Act 2004 (where the powers formerly located only in the High Court are also given to the Family Court) and as far as adults are concerned in the Protection of Personal and Property Rights Act 1988. These powers to intervene are residual ones but no less important for that.

Getting State intervention right is a fraught exercise. When young Liam Williams-Holloway, who eventually died of cancer and who was the centre of an unfortunate media frenzy, was subject to various guardianship orders relating to his medical treatment, the nation was divided. ${ }^{60}$ Had the Court usurped the rights of Liam's parents or was it simply doing its job to try and save the boy's life? Contrast this with the death recently of the two Kahui twin babies and the qualms of conscience that ensued. How could we as a country have allowed this to happen? To take a rather different example of the clash between the actions of society and a parents' rights philosophy, look at the debate surrounding the repeal of section 59 of the Crimes Act 1961, which gives parents a defence of reasonable force when exacting corporal punishment on their children. The parents' lobby groups were not helped by the release of a so-called Christian smacking manual which allows smacking for 10-15 minutes. ${ }^{61}$ This looks like an own goal, yet it graphically raises the question of wider social values versus freedom to parent, and in this instance freedom of religion.

Another aspect of the role of the State is the existence and operation of the Family Court. At one time the Court was considered to be anti-women and there are still feminist challenges, particularly over orders under the Domestic Violence Act $1995 .^{62}$ Strident voices come from the men's groups complaining that the Court is anti-fathers. It is probably impossible for the Court to please everyone all the time, but there have been a couple of developments.

First, the Court has been partly opened up to the media and at the same time a rigorous policy of anonymisation has been introduced. This led Priestley J, prior to his appointment as a High Court Judge one of the bar's leading family law advocates, to protest for several paragraphs at the beginning of a recent judgment. ${ }^{63}$ The upshot was that he gave the parties pseudonyms, Ms Brown and Mr Argyll and called a Bay of Plenty town Lavaton.

60 For one of the judgments - to do with media coverage - see Newspapers Publishers Association of New Zealand (Inc) v Family Court [1999] 2 NZLR 344 (HC, Full Court).

61 Anna Chalmers and Matthew Torbit "Row Over Christian Smacking Manual: Eight-page Booklet Promotes Child Abuse, Say Critics" (19 July 2006) Dominion Post Wellington.

62 A Towns and H Scott "Accountability, Natural Justice and Safety: The Protection Order Pilot Study (POPS) of the Domestic Violence Act 1995" (2006) 5 NZFLJ 157.

63 Brown v Argyll [2006] NZFLR 705 (HC). 
Secondly, the Family Court is experimenting with non-judge led mediation. ${ }^{64}$ There appears to be no statutory authority for this experiment, which relies on contracts between the Ministry of Justice and providers for its legality. It may well be the way of the future - the State playing a more facilitative role rather than an interventionist one - but there are issues here that need to be debated and Parliament is the right place for that debate to take place. Let me quote Michael Freeman again: ${ }^{65}$

Are the parties litigants or patients? ... We may find the adversary processes inappropriate, even

dehumanising and alienating. Yet the formalism and the rule of law which accompany them can provide

a measure of protection to the weak.

It is curious that at the same time as the Family Court is being "opened up", there are fresh efforts to resolve cases in secret by means of mediation.

\section{To Summarise the Picture}

This hasty journey through some of the main parts of family law has thrown up a lot of incongruities. Some of them have been fundamental ones, such as who has prime responsibility for children. Others are at a more detailed level but can still have great impact on individuals at difficult times. In some instances, apparent harmony turns out not to be the case when we examine the law more closely. On the face of it, there is plenty of scope to undertake a project to bring greater harmony to family law, but is it really so easy?

\section{FORCES MILITATING AGAINST HARMONISATION}

Harmonisation ought to bring greater certainty to the law, a desirable aim. Consistency and clarity should mean that people can plan and make decisions with confidence. Processes like mediation and negotiation, which are done in the shadow of the law, ${ }^{66}$ can proceed on a firmer basis. Increasing internationalisation of the law also points us in the direction of harmonisation - in order to be part of the global picture, we need to have our own house in order and in line as much as possible with world-wide trends. All this sounds fine, but is it realistic?

\section{A Diversity}

Much of our family law has been based on the so-called nuclear family. A Western, often individualised, model does not always sit comfortably with Māori tikanga and with the mores of other sections of the community. As already noted, one of the central differences is how a child fits into the world view. For many Europeans, including many politicians, the parent/child relationship is primary. For Māori the primary relationship is with the whānau.

64 Nigel Dunlop "Breaking New Ground: Observations on the Family Mediation Pilot" (2006) 5 NZFLJ 113.

65 Freeman, above n 1, 153 and 163-164.

66 R Mnookin and L Kornhauser "Bargaining in the Shadow of the Law" (1979) 88 Yale LJ 950. 
Yet, the nuclear family is not the basis of the law found in the Families Commission Act 2003. Section 10 is headed "Diversity of New Zealand Families" and is symbolically redolent of a pluralist and multi-cultural society:

(1) In the exercise and performance of its powers and functions, the Commission must have regard to the kinds, structures, and diversity of families.

(2) In this section, family includes a group of people related by marriage, civil union, blood, or adoption, an extended family, 2 or more persons living together as a family, and a whānau or other culturally recognised family group.

(3) However, persons are not members of a family for the purposes of this section solely because they have as their common objective or 1 of their common objectives the achievement of some outcome of a community, domestic, professional, recreational, social, vocational, or other nature (for example, the commission of offences against any enactment, whether to obtain valuable consideration or not).

(4) Subsection (3) is for the avoidance of doubt.

This rare parliamentary attempt to define family is an inclusive, not an exclusive, one. The concept of family is not narrow or restrictive. It does not depend on formal marital status nor on the legal status of the child.

Section 10 may well be designed especially for the research functions of the Families Commission and may not automatically translate to other contexts. Nevertheless, the diversity of families is a reflection not just of different cultures but also of the diversity of values and lifestyles the way in which people actually live. It is a truism to say that across the spectrum there has been very rapid change in attitudes, outstripping the conventional categories that churches, politicians and ethicists have relied on. It was only 20 years ago that homosexual practices were decriminalised. We now have civil unions and in some jurisdictions gay marriage. Could we have imagined this 25 years ago? It is hard to know what to expect in the next 25 years. How can we rationalise all this diversity now, let alone in a way that will stand the test of time?

\section{B Clashing Ideologies}

Diversity is not simply a fact of life. It embraces more fundamental differences than that. When we discussed the disharmony of family law, we noted the different ideological perspectives that impact on any debate. Feminism, men's rights groups, parents' rights groups, children's rights, gay and lesbian calls for justice, religious beliefs and others are all competing for space. It is very hard to expect an easy resolution where there are such clashing voices, all of which are deeply felt and grounded in peoples' own realities.

In any event, should we be disheartened by such variety? An entirely homogenous society may be easy to manage but a cosmopolitan one may in the long run be much richer. One of the most disturbing trends in the world is fundamentalism, whether it be of a religious kind or secular. It 
insists on black and white answers and is rigid in its attitudes to competing views. The alternative, an acceptance of difference even if this is uncomfortable, means that policy development and drafting of the law is much more of a challenge.

\section{Scientific and Technological Advances}

Science, especially medical science, has made enormous strides in the last decades, again in ways that could not have been contemplated when some of our laws were enacted. Those that have had some of the most significant effects on family law have been about reproduction. In vitro fertilisation can mean a disjunction between the birth mother and the genetic parents. Indeed a child may be born to a woman who is neither the genetic mother nor the woman who it is intended will bring the child up. Many of the older legal concepts do not fit these developments, and, with cloning and "designer" babies on the horizon (rightly or wrongly), the law will again be scrambling to keep up. How the law should react attracts widely different views from those who favour a laissez faire approach to those who regard the embryo as a human being, to a range of views in between. In New Zealand, the Human Assisted Reproductive Technology Act 2004 has laid down some principles, but at the same time has put in place a mechanism for new scientific advances to be investigated and debated before legal regulation is determined. ${ }^{67}$

Information technology can also have an impact. Texting and emailing provide new means of contact that were unknown until very recently. This heralds new possibilities for absent parents to keep in touch with their children. What will be the effect on family dynamics?

\section{Human Nature and Dysfunction}

Family law, probably more than any other area of the law, has to deal with human nature, with all the emotions and volatility that is implied. Indeed, family law also tends to deal with dysfunctional families rather than healthy ones. Maurice Gee's recent novel Blindsight is a study in familial dysfunction. In it, Gee says that "[f]amilies are factories for neurosis". 68 Mercifully not all families are like this, but many that come before the Family Court will be, at least for a time. In the face of this, how can family law ever suit everyone's situation?

Many family law issues are therefore not ones that readily lend themselves to predictable outcomes and clear-cut rules. This is especially true when dealing with children, where an element

67 The author has discussed this in "Regulation of Assisted Human Reproduction: The Recent New Zealand Model in Comparison with Other Systems" (2005) 11 Revue Juridique Polynésienne 81.

68 Maurice Gee Blindsight (Penguin Books, Auckland, 2005) 25. The opening line of the novel is frightening: "Father taught us how not to love" (at 5). 
of flexibility may be inevitable and desirable. Indeed, the core concept of the welfare and best interests of the child is at variance with a "one size fits all" model. ${ }^{69}$

\section{E Political Pragmatism}

No harmonisation of family law is possible unless it is politically feasible. The reforms this century have been marked by far less political consensus than in the $20^{\text {th }}$ century, although the radical nature of some of these may reflect a wider representation of views. Legislation such as the Care of Children Act 2004, Property (Relationships) Amendment Act 2001, the Families Commission Act 2003 and the Civil Union Act 2004 passed with small majorities. A government of a different hue may well want to pursue different priorities, perhaps promoting a parents' or a fathers' agenda. We also appear to have reached a stage where it is politically correct not to be politically correct, so long overdue revision of the Adoption Act 1955, including a decision on whether or not civil union and de facto partners should be able to adopt, is likely to remain sidelined.

How to get public and political agreement on the underlying issues which will support any harmonisation is not easy to see. Perhaps there is a job here for the Families Commission. However, even the Commission may be swamped by so many conflicting points of view that in the end it finds the task impossible. A further political reality is that Parliamentarians tend to devote their time to matters of the moment, with the result that there is a lot of tinkering and not a lot of overall strategy. When a piece of legislation like the Care of Children Act 2004 has been passed, Parliament is not likely to return to the subject for some time unless it is to make amendments for discrete purposes. Another complication is that responsibility for various pieces of family legislation is scattered across different government departments. Ensuring that Parliament gets comprehensive and consistent advice is not easy.

\section{F The Boundaries of Family Law}

Another difficulty with a harmonisation project is the uncertainty over what would fall within its scope. When family law was basically about marriage and children it may have been easy. However, today it is about couples, parents, children, families, caregivers, the State, iwi and adults with mental health problems or intellectual disabilities. There can be health issues that affect these relationships. Increasingly it is creeping into inheritance matters (another whole topic). What about child-care facilities and education? After all, schools sometimes spend more time with children than do the parents and yet the teacher/pupil relationship is not unproblematic. Harmonisation would have to have some boundaries but, as soon as boundaries are set, there is the risk of new incongruities.

69 This is superbly discussed by Professor Graeme Austin in Children: Stories the Law Tells (Victoria University Press, Wellington, 1994). Among others, he draws on Robert Mnookin's notion of indeterminacy in: "Child-Custody Adjudication: Judicial Functions in the Face of Indeterminacy" (1975) 39 L \& CP 226. 


\section{DRAWING SOME THREADS TOGETHER}

John Dewar of Griffith University entitled his inaugural "Family Law and Its Discontents". 70 That does not augur well if we are in search of coherence. He had earlier written an article entitled "The Normal Chaos of Family Law". ${ }^{71}$ Much of what I have said suggests that in our society today there is a very mixed bag of pressures and philosophies that has left a considerable degree of chaos in the formularies of family law. Perhaps this is inevitable and like good post-modern people we should settle down to a life of ambiguity.

That somehow does not satisfy in the end. The law surely needs a little more certainty than that. This is especially so in relation to economic issues, where there is already some homogeneity, although rather less when one unpacks the law in greater detail. In relation to children, it may be harder to find consensus, because as soon as we go beyond the core principle of the child's welfare and best interests we hit cultural and ideological tensions.

In this lecture I have sketched the law's state of disharmony. I have also listed a range of factors that suggest that the quest for harmony may be forlorn. I have not provided a blueprint for harmonisation nor even a set of key values that should drive harmonisation. Perhaps we should pursue these tasks if we wish to have a little less chaos than at present.

70 John Dewar "Family Law and its Discontents" (2000) 14 IJLPF 59.

71 John Dewar "The Normal Chaos of Family Law" (1998) 61 MLR 467. 
